\title{
STUDI GENANGAN KAWASAN BANJARMASIN UTARA KOTA BANJARMASIN
}

\section{Study of Puddles in North Banjarmasin Area Banjarmasin City}

\author{
Fitriansyah $^{1}$, Akhmad Sibawaihi ${ }^{2}$ \\ ${ }^{1,2}$ Teknik Sipil Universitas Acmad Yani Banjarmasin \\ Alamat korespondesi: \\ Jalan A.Yani km. 5,5 Komplek Stadion Lambung Mangkurat, Telp. (0511)3253850 \\ e-mail: fitriansyah25@yahoo.co.id
}

\begin{abstract}
Banjarmasin city known as the City of a Thousand Rivers located downstream of Martapura River which empties into the Barito River in Banjarmasin city administration has five regions namely North Banjarmasin district, Central Banjarmasin, Banjarmasin Barat, Banjarmasin East, and South Banjarmasin. In the spatial plan Banjarmasin Banjarmasin northern region is one satuPusatPelayanan City as a major growth center and activity center urban area, therefore it is necessary to do studies Puddle North Banjarmasin region to deal with puddles Intheregion. Inundation occurred in Banjarmasin caused by tidal river water, rain or rain along with river water pasang.Dalam stud igenangan North Banjarmasin area of data collection survey conducted by the puddle, causing inundation, tidal river survey, then do inundation mapping. To achieve the objective of this study should be conducted stages of analysis include: Analysis of Hydrology pinpoint rainfall average and calculate the flood discharge plan (the peak discharge runoff) in the watershed, analysis of inundation with rising water level which simulated the map and inundation map projected on a map in some sub-basins, namely the sub-basins wish, Awang sub-basins, sub-basins Jahri Saleh, Kedaung sub watersheds and sub-watersheds Kuin.
\end{abstract}

Keywords : North Banjarmasin, Location Puddle, Puddles Cause.

\begin{abstract}
Abstrak
Kota Banjarmasin yang dikenal sebagai Kota Seribu Sungai terletak di bagian hilir Sungai Martapura yang bermuara di Sungai Barito secara administrasi pemerintahan Kota Banjarmasin memiliki lima kawasan yaitu kawasan Banjarmasin Utara, Banjarmasin Tengah, Banjarmasin Barat, Banjarmasin Timur, dan Banjarmasin Selatan. Dalam rencana tata ruang kota Banjarmasin kawasan Banjarmasin utara merupakan salah satuPusatPelayanan Kota sebagai pusat pertumbuhan utama dan pusat kegiatan wilayah perkotaan, Oleh sebab itu sangat perlu untuk dilakukan Studi Genangan kawasan Banjarmasin Utara untuk menangani genangan di wilayah tersebut. Genangan yang terjadi di Kota Banjarmasin disebabkan oleh air sungai pasang, air hujan maupun hujan yang bersamaan dengan air sungai pasang.Dalam stud igenangan kawasan Banjarmasin Utara dilakukan dengan pengumpulan data survey genangan, penyebab genangan, survey pasang surut sungai, kemudian dilakukan pemetaan genangan. Untuk mencapai tujuan dari studi ini maka perlu dilakukan tahapan-tahapan analisis berupa : Analisa Hidrologi untuk mengetahi curah hujan rata-rata dan menghitung debit banjir rencana (debit puncak limpasan permukaan) pada DAS, analisa genangan dengan kenaikan elevasi muka air yang di simulasikan dalam peta, dan peta genangan yang diproyeksikan pada peta dibeberapa sub DAS yaitu pada sub DAS Andai, sub DAS Awang, sub DAS Jahri Saleh, sub DAS Kedaung, dan sub DAS Kuin.
\end{abstract}

Kata Kunci: Banjarmasin Utara, Lokasi Genangan,Penyebab Genangan.

\section{PENDAHULUAN}

Kota Banjarmasin yang dikenal sebagai Kota Seribu Sungai terletak di bagian hilir Sungai Martapura yang bermuara di Sungai Barito secara administrasi pemerintahan memiliki lima 
kawasan yaitu kawasan Banjarmasin Utara, Banjarmasin Tengah, Banjarmasin Barat, Banjarmasin Timur, dan Banjarmasin Selatan. Sebagian besar wilayah kota awalnya merupakan daerah rawa dimana selalu tergenang air yang dipengaruhi oleh permukaan air sungai yang mengikuti pasang-surut air laut.

Pada saat air laut pasang terjadi aliran balik ke sungai - sungai dan saluran drainase sesehingga permukaan air lebih tinggi dan sebagian besar lahan dan menyebabkan terjadinya genangangenangan pada daerah daerah dengan topografi rendah. Genangan semakin luas dan dalam bila terjadi hujan yang bersamaan dengan pasang air sungai.

Dalam rencana tata ruang kota Banjarmasin kawasan Banjarmasin utara merupakan salah satu pusat pelayanan kota sebagai pusat pertumbuhan utama dan pusat kegiatan wilayah perkotaan. Oleh sebab itu sangat perlu untuk dilakukan Studi Genangan kawasan Banjarmasin Utara untuk menangani genangan di wilayah tersebut, dimana nantinya akan teridentifikasi lokasi genangan, waktu tergenang, ke dalaman genangan, dan proyeksi genangan di tahun mendatang serta pola penanganannya.

Penelitian ini diharapkan mampu mendapatkan proyeksi peta genangan pada Kawasan Banjarmasin Utara dan mengidentifikasi penyebab genangan di Kawasan Banjarmasin Utara. Selain itu, hasil penelitian ini dapat memberikan manfaat dalam menyediakan data-data dasar untuk mendukung penanganan genangan di kawasan Banjarmasin Utara.

\section{Analisa Hidrologi}

- Distribusi Normal

Perhitungan Distribusi Gumble dengan menggunakan persamaan sebagai berikut;

$$
X T=\bar{X}+k T . S
$$

Keterangan :

$X T$ : besarnya suatu kejadian dengan periode ulang $\mathrm{T}$ tahunan

$\bar{X}:$ nilai rata - rata

$S$ : standar t deviasi

$k T$ : faktor sifat dari Normal.

- Distribusi Log Normal
Perhitungan Distribusi Log Normal dengan menggunakan persamaan sebagai berikut

$$
X T=\bar{X}+k T \cdot S
$$

Keterangan :

$X T$ : besarnya suatu kejadian dengan periode ulang $\mathrm{T}$ tahunan

$$
\begin{array}{ll}
\bar{X} & \text { : nilai rata - rata } \\
S & \text { : standar t deviasi } \\
k T & : \text { faktor sifat dari } \log \\
& \text { Normal. }
\end{array}
$$

- Distribusi Gumbel

Perhitungan Distribusi Gumble dengan menggunakan persamaan sebagai berikut

$$
X=\bar{X}+k \cdot S
$$

Keterangan :

$$
\begin{array}{ll}
X & \text { : besarnya suatu kejadian } \\
\bar{X} & \text { : nilai rata }- \text { rata } \\
S & \text { : standar t deviasi } \\
k & : \text { faktor sifat dari Gumble. }
\end{array}
$$

- Distribusi Log Pearson Tipe III Perhitungan Distribusi Log Pearson Tipe III dengan menggunakan persamaan sebagai berikut

$$
\log X=\overline{\log X}+k \cdot \overline{S \log X}
$$

$$
\begin{aligned}
& \text { Keterangan : } \\
& X \quad \text { : besarnya suatu kejadian } \\
& \overline{\log X} \quad \text { : nilai rata - rata } \\
& \overline{S \log X} \text { : standart deviasi } \\
& k \quad \text { : faktor sifat dari Distribusi } \\
& \text { Log Pearson Tipe III } \\
& \text { yang besarnya } \\
& \text { tergantung koefesien } \\
& \text { kemencengan. }
\end{aligned}
$$

\section{Pemetaan Menggunakan Program Global Mapper.13}

Software yang akan digunakan dalam permodelan genangan yaitu Global Mapper 13. Global Mapper adalah salah satu perangkat lunak yang cukup populer sering digunakan oleh kalangan praktisi 
GIS (geographics information system) atau orang-orang yang berkecimpung di bidang pemetaan. Salah satu keistimewaan program ini adalah kompatibilitasnya dengan banyak sekali format file. Sehingga dapat digunakan oleh banyak orang dari latar belakang pengetahuan perangkat lunak lain yang berbeda-beda.

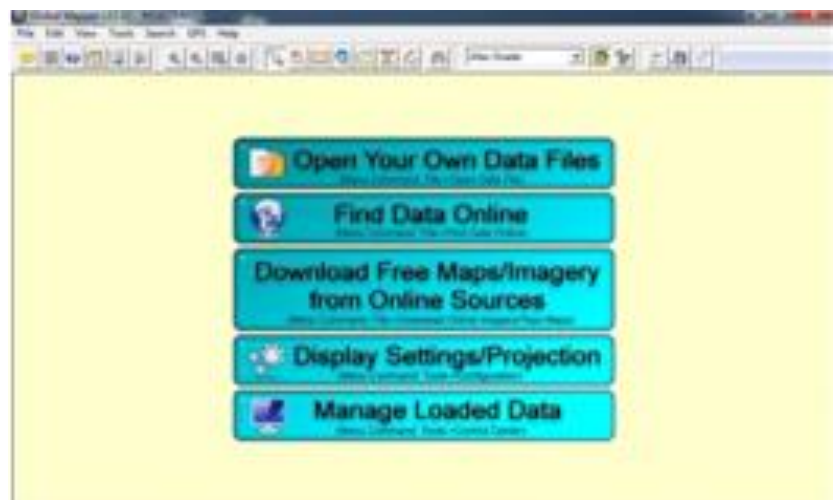

Gambar 1. Tampilan utama Global Mapper

Global Mapper bukan sekadar perangkat serbaguna, namun memiliki fungsi builtin untuk perhitungan jarak dan area, pembauran arsir dan penyesuaian kontras, melihat elevasi, dan perhitungan garis pandang, serta kemampuan tingkat lanjut seperti rektifikasi citra, pembuatan kontur dari data permukaan, analisis tampilan arah aliran dari data permukaan, serta triangulasi dan melakukan gridding data titik 3D. Tugas berulang dapat diselesaikan dengan menggunakan fungsi bahasa script yang built-in atau konversi batch secara menyeluruh.

\section{METODE PENELITIAN}

\section{Lokasi Penelitian}

Kawasan banjarmasin utara secara administrasi Pemerintahan Kota Banjarmasin berada di wilayah kecamatan Banjarmasin Utara dengan luas wilayah \pm $22,25 \mathrm{Km}^{2}$.

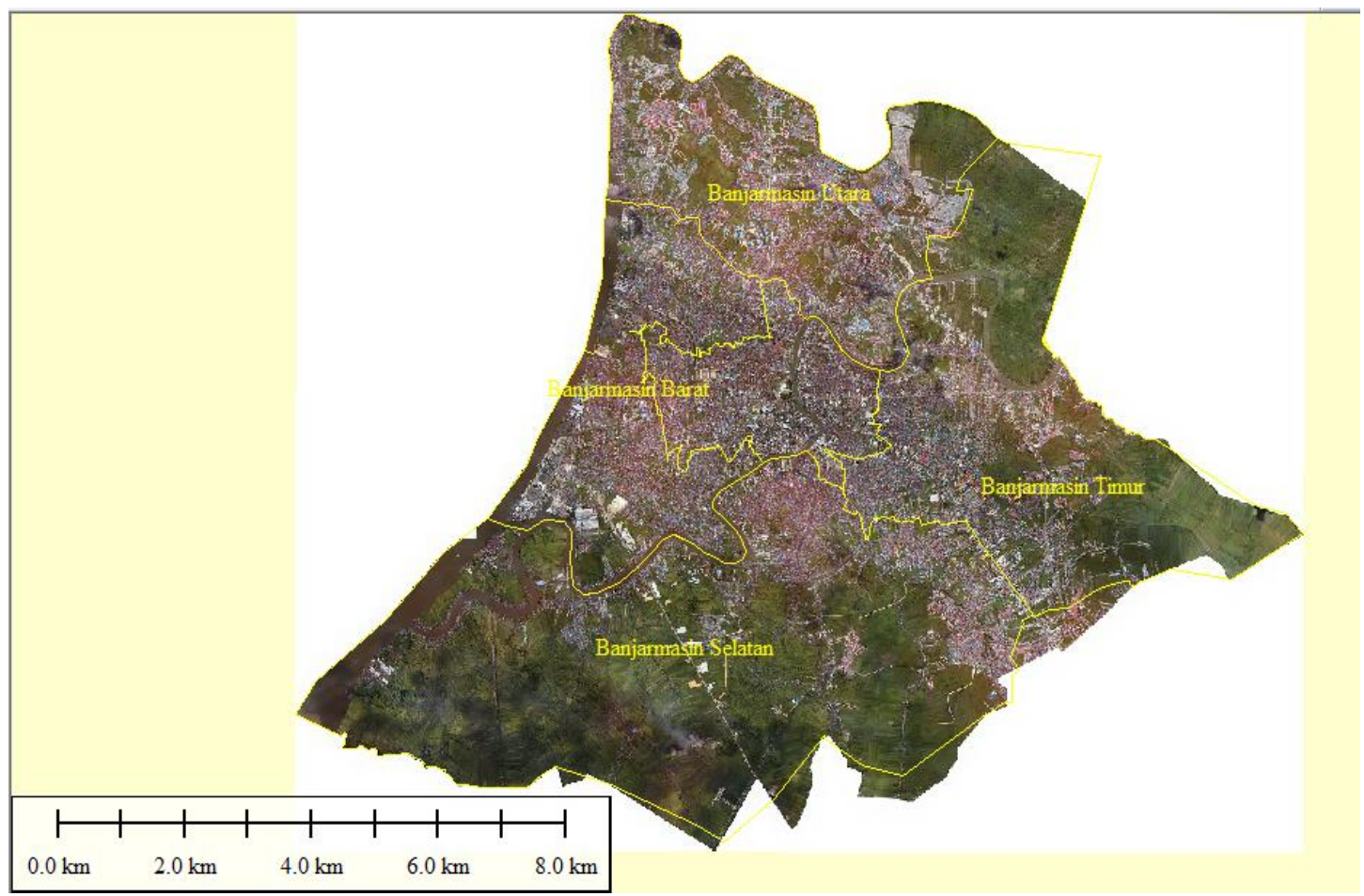

Gambar 2. Pembagian Kawasan Kota Banjarmasin 


\section{Pengumpulan Data}

- Data Sekunder diantaranya;

- Peta kontur/tofografi

- Peta foto udara

- Peta jaringan sungai

- Data hujan

- Data Primer diantaranya;

- Melakukan survey genangan.

- Melakukan survey jaringan saluran sungai dan drainase.

- Melakukan survey pasang surut.

\section{HASIL DAN PEMBAHASAN}

\section{Analisa Hidrologi}

Stasiun hujan yang digunakan dalam analisa ini adalah stasiun hujan Surgi Mufti yang ada di kota Banjarmasin. Distribusi frekuensi yang digunakan dalam analisa ini yaitu metode gumbel, $\log$ pearson tipe III, dan $\log$ normal. Adapun data hujan maksimum adalah sebagai berikut:

\section{Hujan Surgi Mufti}

- Metode Gumbel

Tabel 1. Hujan maksimum harian Stasiun Surgi Mufti

\begin{tabular}{ccc}
\hline No & Tahun & R maks $(\mathbf{m m})$ \\
\hline 1 & 1999 & 91 \\
2 & 2000 & 168 \\
3 & 2001 & 90 \\
4 & 2002 & 59 \\
5 & 2003 & 75 \\
6 & 2004 & 55 \\
7 & 2005 & 54 \\
8 & 2006 & 61 \\
9 & 2007 & 69 \\
10 & 2008 & 61 \\
11 & 2009 & 49.1 \\
12 & 2010 & 50 \\
13 & 2011 & 55 \\
14 & 2012 & 66 \\
\hline
\end{tabular}

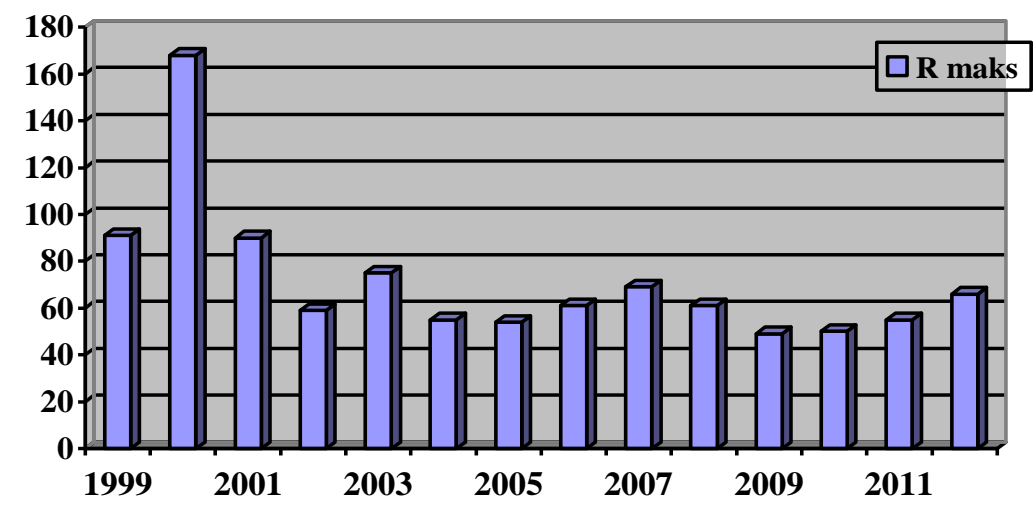

Gambar 2. Hujan maksimum harian stasiun Surgi Mufti

Tabel 2. Hujan maksimum dan karakteristiknya Stasiun Surgi Mufti

\begin{tabular}{cccccc}
\hline No & Kejadian & $\mathrm{x}_{\mathrm{i}}$ & $\left(\mathrm{x}_{\mathrm{i}}-\mathrm{x}\right)$ & $\left(\mathrm{x}_{\mathrm{i}}-\mathrm{x}\right)^{2}$ & $\left(\mathrm{x}_{\mathrm{i}}-\mathrm{x}\right)^{3}$ \\
\hline 1 & 2000 & 168 & 96.35 & 9283.32 & 894448,12 \\
2 & 1999 & 91 & 19.35 & 374.42 & 7245.08 \\
3 & 2001 & 90 & 18.35 & 336.72 & 6178.86 \\
4 & 2003 & 75 & 3.35 & 11.22 & 37.60 \\
5 & 2007 & 69 & -2.65 & 7.02 & -18.61 \\
6 & 2012 & 66 & -5.65 & 31.92 & -180.36 \\
7 & 2006 & 61 & -10.65 & 113.42 & -1207.95 \\
8 & 2008 & 61 & -10.65 & 113.42 & 1207.95 \\
9 & 2002 & 59 & -12.65 & 160.02 & -2024.95 \\
10 & 2004 & 55 & -16.65 & 277.22 & -4615.75 \\
11 & 2011 & 55 & -16.65 & 277.22 & 4615.75 \\
12 & 2005 & 54 & -17.65 & 311.52 & -5498.37 \\
13 & 2010 & 50 & -21.65 & 468.72 & -10147.84 \\
14 & 2009 & 49.1 & -22.55 & 508.5 & -11466.73 \\
\hline \multicolumn{7}{c}{ Rata-rata } & 71.65 & $-5.5 . \mathrm{E}-15$ & 876.76 & -61923.29 \\
\hline
\end{tabular}


Tabel 3. Hujan Rencana Metode Gumbel Stasiun Surgi Mufti

\begin{tabular}{cccccc}
\hline TP & Y & K & V rata-rata & Simp baku & XT \\
\hline 2.00 & 0.367 & -0.130 & 71.65 & 30.73 & 67.66 \\
5.00 & 1.500 & 1.011 & 71.65 & 30.73 & 102.72 \\
10.00 & 2.250 & 1.766 & 71.65 & 30.73 & 125.93 \\
15.00 & 2.674 & 2.192 & 71.65 & 30.73 & 139.02 \\
20.00 & 2.970 & 2.491 & 71.65 & 30.73 & 148.19 \\
25.00 & 3.199 & 2.721 & 71.65 & 30.73 & 155.25 \\
50.00 & 3.902 & 3.419 & 71.65 & 30.73 & 177.01 \\
100.00 & 4.600 & 4.131 & 71.65 & 30.73 & 198.60 \\
200.00 & 5.296 & 4.832 & 71.65 & 30.73 & 220.11 \\
400.00 & 5.990 & 5.530 & 71.65 & 30.73 & 241.59 \\
\hline
\end{tabular}

Tabel 4. Karakteristik data hujan stasiun Surgi Mufti

\begin{tabular}{cc}
\hline Karakteristik data & Nilai \\
\hline X rerata & 71.65 \\
X median & 61.00 \\
Simpangan baku & 30.73 \\
Skewness Coefisien & 2.68 \\
Varuant coefisien & 2.33 \\
\hline
\end{tabular}

Tabel 5. Perhitungan probabilitas hujan rencana menurut Gumbel Stasiun Surgi Mufti

\begin{tabular}{|c|c|c|c|c|c|c|c|c|c|c|c|}
\hline $\mathrm{m}$ & m' & $\mathrm{x}$ & $\begin{array}{c}\mathrm{C} \\
=\mathrm{m}^{\prime} / \mathrm{N}\end{array}$ & $\begin{array}{c}\mathrm{T} \\
\mathrm{t} /(\mathrm{m}+\mathrm{c} \\
-1)\end{array}$ & $\begin{array}{c}\mathrm{P}=(1 / \\
\mathrm{T})\end{array}$ & $\begin{array}{c}\mathrm{Y}= \\
-\ln (- \\
\ln (1- \\
(1 / \mathrm{T})))\end{array}$ & $\begin{array}{c}\text { X rata- } \\
\text { rata }\end{array}$ & $\begin{array}{l}\text { Simp } \\
\text { baku }\end{array}$ & $\begin{array}{c}\mathrm{Xt}=\mathrm{Xax} \\
+ \\
\mathrm{Sx}(0.78 \\
\mathrm{y}-0.45)\end{array}$ & $\Delta$ & $\begin{array}{c}(y- \\
y n)^{2}\end{array}$ \\
\hline 1 & 14 & 168 & 100 & 14 & 0.071 & 2.602 & 71.650 & 30.728 & 120.192 & 47.808 & 4.439 \\
\hline 2 & 13 & 91 & 92.857 & 7.259 & 0.138 & 1.909 & 71.650 & 30.728 & 103.579 & 12.579 & 1.998 \\
\hline 3 & 12 & 90 & 85.714 & 4.9 & 0.204 & 2.477 & 71.650 & 30.728 & 93.229 & 3.229 & 0.964 \\
\hline 4 & 11 & 75 & $78 / 571$ & 3.698 & 0.270 & 2.254 & 71.650 & 30.728 & 85.489 & 10.489 & 0.434 \\
\hline 5 & 10 & 69 & 71.429 & 2.97 & 0.337 & 0.890 & 71.650 & 30.728 & 79.158 & 10.158 & 0.156 \\
\hline 6 & 9 & 66 & 64.286 & 2.481 & 0.403 & 0.662 & 71.650 & 30.728 & 73.683 & 7.683 & 0.028 \\
\hline 7 & 8 & 61 & 57.143 & 2.130 & 0.469 & 0.456 & 71.650 & 30.728 & 68.755 & 7.755 & 0.002 \\
\hline 8 & 7 & 61 & 50 & 1.867 & 0.536 & 0.265 & 71.650 & 30.728 & 64.172 & 3.172 & 0.053 \\
\hline 9 & 6 & 59 & 42.857 & 1.661 & 0.602 & 0.082 & 71.650 & 30.728 & 59.784 & 0.784 & 0.171 \\
\hline 10 & 5 & 55 & 35.714 & 1.496 & 0.668 & -0.099 & 71.650 & 30.728 & 55.457 & 0.457 & 0.353 \\
\hline 11 & 4 & 55 & 28.571 & 1.361 & 0.735 & -0.283 & 71.650 & 30.728 & 51.044 & 3.956 & 0.606 \\
\hline 12 & 3 & 54 & 21.429 & 1.248 & 0.801 & -0.479 & 71.650 & 30.728 & 46.340 & 7.660 & 0.950 \\
\hline 13 & 2 & 50 & 14.286 & 1.153 & 0.867 & -0.703 & 71.650 & 30.728 & 40.970 & 9.030 & 1.436 \\
\hline 14 & 1 & 49.1 & 7.143 & 1.071 & 0.934 & -0.998 & 71.650 & 30.728 & 33.970 & 15.200 & 2.231 \\
\hline$X$ & 71.650 & $\mathrm{CS}$ & 2.682 & & & $\mathrm{X}$ & 69.697 & $\mathrm{CS}$ & 0.551 & & \\
\hline$\varphi$ & 30.728 & $\mathrm{CV}$ & 2.332 & & & $\varphi$ & 24.712 & $\mathrm{CV}$ & 2.820 & & \\
\hline
\end{tabular}

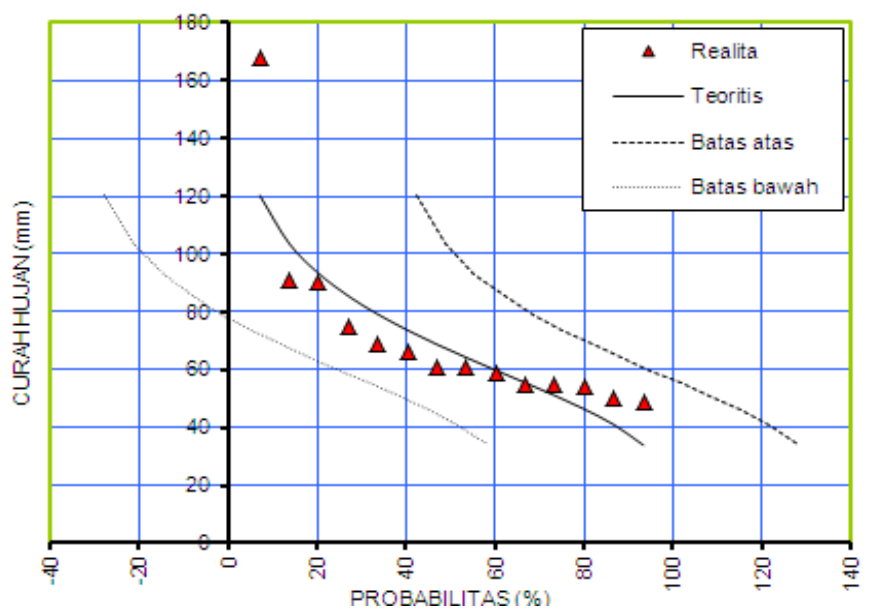

Gambar 3. Hubungan antara probabilitas dan curah hujan Surgi Mufti menurut metode Gumbel 
Menghitung $X^{2} \mathrm{cr}$

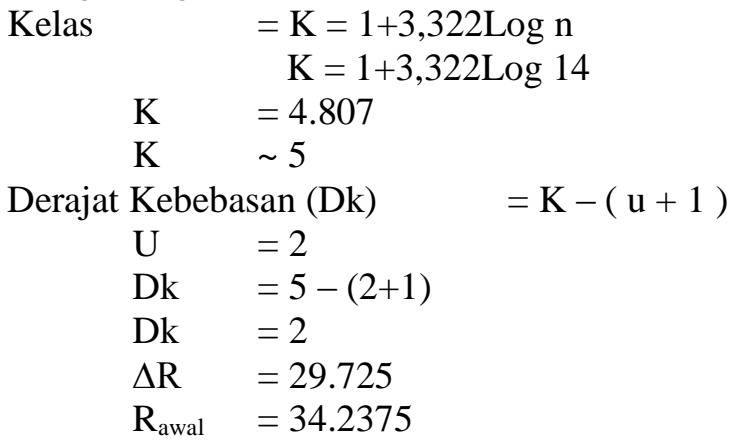

Didapatkan Dk $=2.000, \alpha=0.05$ maka pada Chi Square didapat $X^{2} \mathrm{cr}=5.991$

Tabel 6. Analisa Chi Square

\begin{tabular}{|c|c|c|c|c|c|c|}
\hline \multicolumn{3}{|c|}{ Inerval Data Curah Hujan } & \multirow{2}{*}{$\begin{array}{c}\begin{array}{c}\text { Ecpected } \\
\text { (EF) }\end{array} \\
2.8\end{array}$} & \multirow{2}{*}{$\begin{array}{c}\text { Observased } \\
(\mathrm{OF})\end{array}$} & \multirow{2}{*}{$\begin{array}{c}(\mathrm{EF}-\mathrm{OF}) \\
-5.2\end{array}$} & \multirow{2}{*}{$\frac{(\mathrm{EF}-\mathrm{OF})^{2}}{27.040}$} \\
\hline 34.238 & - & 63.963 & & & & \\
\hline 63.963 & - & 93.688 & 2.8 & 5 & -2.2 & 4.840 \\
\hline 93.688 & - & 123.41 & 2.8 & 0 & 2.8 & 7.840 \\
\hline 123.41 & - & 153.14 & 2.8 & 0 & 2.8 & 7.840 \\
\hline 153.14 & - & 182.86 & 2.8 & 1 & 1.8 & 3.240 \\
\hline \multicolumn{3}{|c|}{ Jumlah } & 14 & 14 & 0 & 50.800 \\
\hline
\end{tabular}

$\mathrm{X}^{2}$ hit $=\frac{\sum(\mathrm{EF}-\mathrm{OF})^{2}}{\sum \mathrm{EF}}=3.629$

Maka $3.629<5.991 \quad\left(\mathrm{X}^{2} \mathrm{hit}<\mathrm{X}^{2} \mathrm{cr}\right) \rightarrow$ diterima

\section{b. Metode Log Pearson type III}

Tabel 7. Perhitungan hujan rencana log Pearson Type III Stasiun Surgi Mufti

\begin{tabular}{|c|c|c|c|c|c|c|}
\hline No & Kejadian & $\mathrm{X}_{\mathrm{i}}$ & $\log x$ & $\left(x_{i}-x\right)$ & $\left(x_{i}-x\right)^{2}$ & $\left(x_{i}-x\right)^{3}$ \\
\hline 1 & 2000 & 168 & 2.23 & 96.35 & 9283.32 & 894448,12 \\
\hline 2 & 1999 & 91 & 1.96 & 19.35 & 374.42 & 7245.08 \\
\hline 3 & 2001 & 90 & 1.95 & 18.35 & 336.72 & 6178.86 \\
\hline 4 & 2003 & 75 & 1.88 & 3.35 & 11.22 & 37.60 \\
\hline 5 & 2007 & 69 & 1.84 & -2.65 & 7.02 & -18.61 \\
\hline 6 & 2012 & 66 & 1.82 & -5.65 & 31.92 & -180.36 \\
\hline 7 & 2006 & 61 & 1.79 & -10.65 & 113.42 & -1207.95 \\
\hline 8 & 2008 & 61 & 1.79 & -10.65 & 113.42 & 1207.95 \\
\hline 9 & 2002 & 59 & 1.77 & -12.65 & 160.02 & -2024.95 \\
\hline 10 & 2004 & 55 & 1.74 & -16.65 & 277.22 & -4615.75 \\
\hline 11 & 2011 & 55 & 1.74 & -16.65 & 277.22 & 4615.75 \\
\hline 12 & 2005 & 54 & 1.73 & -17.65 & 311.52 & -5498.37 \\
\hline 13 & 2010 & 50 & 1.70 & -21.65 & 468.72 & -10147.84 \\
\hline 14 & 2009 & 49.1 & 1.69 & -22.55 & 508.5 & -11466.73 \\
\hline \multicolumn{2}{|c|}{ Jumlah } & 1003.10 & 25.617 & 0 & 12274.695 & 866926.041 \\
\hline \multicolumn{2}{|c|}{ Rata-rata } & 71.65 & 1.830 & 0 & 876.76 & 61923.29 \\
\hline
\end{tabular}


Tabel 8. Hujan Rencana Metode Log Pearson Type III Stasiun Surgi Mufti

\begin{tabular}{ccccccccc}
\hline TP & $\mathrm{P}$ & $\mathrm{W}$ & $\mathrm{Z}$ & $\mathrm{K}$ & $\begin{array}{c}\text { Log X } \\
\text { rata-rata }\end{array}$ & $\begin{array}{c}\text { Simp } \\
\text { baku }\end{array}$ & Log XT & XT \\
\hline 2.00 & 0.5 & 1.177 & 0 & -0.337 & 1.830 & 0.141 & 1.782 & 60.54 \\
5.00 & 0.2 & 1.794 & 0.841 & 0.610 & 1.830 & 0.141 & 1.916 & 82.42 \\
10.00 & 0.1 & 2.146 & 1.282 & 1.334 & 1.830 & 0.141 & 2.019 & 104.35 \\
15.00 & 0.067 & 2.327 & 1.501 & 1.761 & 1.830 & 0.141 & 2.079 & 119.93 \\
20.00 & 0.05 & 2.448 & 1.645 & 2.066 & 1.830 & 0.141 & 2.122 & 132.44 \\
25.00 & 0.04 & 2.537 & 1.751 & 2.303 & 1.830 & 0.141 & 2.156 & 143.09 \\
50.00 & 0.02 & 2.797 & 2.054 & 3.046 & 1.830 & 0.141 & 2.261 & 182.27 \\
100.00 & 0.01 & 3.035 & 2.327 & 3.798 & 1.830 & 0.141 & 2.367 & 232.84 \\
200.00 & 0.005 & 3.255 & 2.576 & 4.559 & 1.830 & 0.141 & 2.475 & 298.32 \\
400.00 & 0.025 & 3.462 & 2.807 & 5.329 & 1.830 & 0.141 & 2.584 & 383.34 \\
\hline
\end{tabular}

Tabel 9. Karakteristik data hujan Metode Log Pearson Type III stasiun Surgi Mufti

\begin{tabular}{cc}
\hline Karakteristik data & Nilai \\
\hline X rerata & 1.830 \\
X median & 1.785 \\
Simpangan baku & 0.141 \\
Skewness Coefisien & 1.53 \\
Varuant coefisien & 12.935 \\
\hline
\end{tabular}

Tabel 10. Perhitungan probabilitas hujan rencana menurut Log Pearson Type III Stasiun Surgi Mufti

\begin{tabular}{ccccccccccc}
\hline $\mathrm{m}$ & $\mathrm{x}$ & $\log \mathrm{X}$ & $\begin{array}{c}\mathrm{P}=\mathrm{m} /( \\
\mathrm{n}+1)\end{array}$ & $\mathrm{W}$ & $\mathrm{Z}$ & $\mathrm{K}$ & $\begin{array}{c}\text { Log X } \\
\text { rata-rata }\end{array}$ & $\begin{array}{c}\text { Simp } \\
\text { baku }\end{array}$ & Log XT & $\mathrm{XT}$ \\
\hline 1 & 168 & 2.225 & 0.067 & 2.327 & 1.501 & 1.761 & 1.830 & 0.141 & 2.079 & 119.93 \\
2 & 91 & 1.959 & 0.133 & 2.007 & 1.111 & 1.033 & 1.830 & 0.141 & 1.976 & 94.59 \\
3 & 90 & 1.954 & 0.2 & 1.794 & 0.841 & 0.610 & 1.830 & 0.141 & 1.916 & 82.42 \\
4 & 75 & 1.875 & 0.267 & 1.626 & 0.623 & 0.331 & 1.830 & 0.141 & 1.874 & 74.78 \\
5 & 69 & 1.839 & 0.333 & 1.482 & 0.430 & 0.080 & 1.830 & 0.141 & 1.841 & 69.36 \\
6 & 66 & 1.820 & 0.4 & 1.354 & 0.253 & -0.108 & 1.830 & 0.141 & 1.814 & 65.23 \\
7 & 61 & 1.785 & 0.467 & 1.235 & 0.083 & -0.267 & 1.830 & 0.141 & 1.792 & 61.95 \\
8 & 61 & 1.785 & 0.533 & 1.121 & -0.083 & -0403 & 1.830 & 0.141 & 1.773 & 59.26 \\
9 & 59 & 1.771 & 0.6 & 1.011 & -0.252 & -0.523 & 1.830 & 0.141 & 1.756 & 57.00 \\
10 & 55 & 1.740 & 0.667 & 0.901 & -0.428 & -0.628 & 1.830 & 0.141 & 1.741 & 55.07 \\
11 & 55 & $1 / 740$ & 0.733 & 0.788 & -0.616 & -0.721 & 1.830 & 0.141 & 1.728 & 53.43 \\
12 & 54 & 1.732 & 0.8 & 0.668 & -0.829 & -0.801 & 1.830 & 0.141 & 1.716 & 52.05 \\
13 & 50 & 1.699 & 0.867 & 0.535 & -1.084 & -0.868 & 1.830 & 0.141 & 1.707 & 50.94 \\
14 & 49.1 & 1.691 & 0.933 & 0.371 & -1.435 & -0.909 & 1.830 & 0.141 & 1.701 & 50.25 \\
\hline & Realita & & & & & & Teoritis & & & \\
\hline $\mathrm{X}$ & 71.650 & $\mathrm{CS}$ & 2.682 & & & & $\mathrm{X}$ & 69.697 & $\mathrm{CS}$ & 1.671 \\
$\varphi$ & 30.728 & $\mathrm{CV}$ & 2.332 & & & & & & & \\
\hline
\end{tabular}

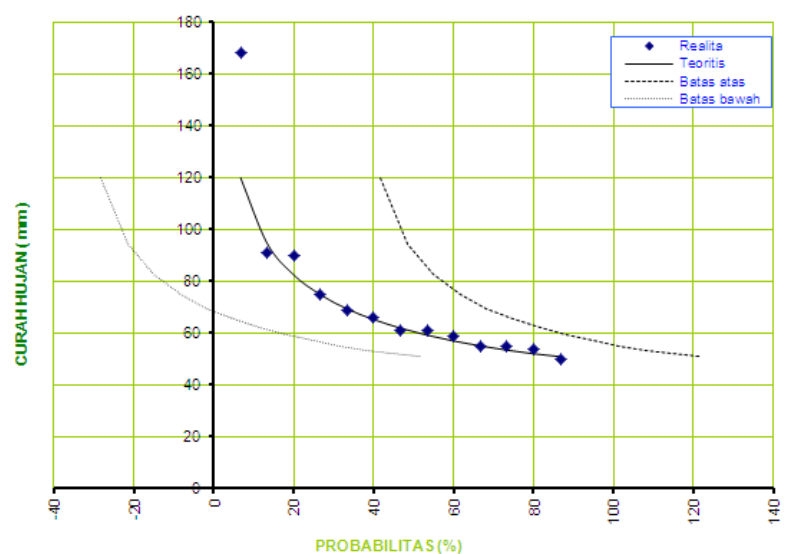

Gambar 4. Hubungan antara probabilitas dan curah hujan Surgi Mufti menurut metode Log Pearson type III 


\section{c. Metode log Normal}

Tabel 11. Perhitungan hujan rencana log Normal Stasiun Surgi Mufti

\begin{tabular}{|c|c|c|c|c|c|c|}
\hline No & Kejadian & $\mathrm{X}_{\mathrm{i}}$ & $\log x$ & $\left(\mathrm{x}_{\mathrm{i}}-\mathrm{x}\right)$ & $\left(x_{i}-x\right)^{2}$ & $\left(x_{i}-x\right)^{3}$ \\
\hline 1 & 2000 & 168 & 2.23 & 0.39554 & 0.15645 & 0.06188 \\
\hline 2 & 1999 & 91 & 1.96 & 0.12927 & 0.01671 & 0.00216 \\
\hline 3 & 2001 & 90 & 1.95 & 0.12448 & 0.01549 & 0.00193 \\
\hline 4 & 2003 & 75 & 1.88 & 0.04529 & 0.00205 & 0.00009 \\
\hline 5 & 2007 & 69 & 1.84 & 0.00908 & 0.00008 & 0 \\
\hline 6 & 2012 & 66 & 1.82 & -0.01022 & 0.00010 & 0 \\
\hline 7 & 2006 & 61 & 1.79 & -0.04444 & 0.00197 & -0.00009 \\
\hline 8 & 2008 & 61 & 1.79 & -0.04444 & 0.00197 & -0.00009 \\
\hline 9 & 2002 & 59 & 1.77 & -0.05891 & 0.00347 & -0.00020 \\
\hline 10 & 2004 & 55 & 1.74 & -0.08940 & 0.00799 & -0.00071 \\
\hline 11 & 2011 & 55 & 1.74 & -0.08940 & 0.00799 & -0.00071 \\
\hline 12 & 2005 & 54 & 1.73 & -0.09737 & 0.00948 & -0.00092 \\
\hline 13 & 2010 & 50 & 1.70 & -0.13080 & 0.01711 & -0.00224 \\
\hline 14 & 2009 & 49.1 & 1.69 & -0.13868 & 0.01923 & -0.00267 \\
\hline \multicolumn{2}{|c|}{ Jumlah } & 1003.10 & 25.617 & 0 & 0.26 & 0.05843 \\
\hline \multicolumn{2}{|c|}{ Rata-rata } & 71.65 & 1.830 & 0 & 0.0186 & 0.004173 \\
\hline
\end{tabular}

Tabel 12. Hujan Rencana Stasiun Surgi Mufti

\begin{tabular}{ccccccccc}
\hline $\mathrm{TP}$ & $\mathrm{P}$ & $\mathrm{W}$ & $\mathrm{Z}$ & $\mathrm{K}$ & $\begin{array}{c}\text { Log X } \\
\text { rata-rata }\end{array}$ & $\begin{array}{c}\text { Simp } \\
\text { baku }\end{array}$ & Log XT & XT \\
\hline 2.00 & 0.5 & 1.177 & 0 & 0 & 1.830 & 0.141 & 1.830 & 67.57 \\
5.00 & 0.2 & 1.794 & 0.841 & 0.841 & 1.830 & 0.141 & 1.949 & 88.88 \\
10.00 & 0.1 & 2.146 & 1.282 & 1.282 & 1.830 & 0.141 & 2.011 & 102.58 \\
15.00 & 0.067 & 2.327 & 1.501 & 1.501 & 1.830 & 0.141 & 2.042 & 110.19 \\
20.00 & 0.05 & 2.448 & 1.645 & 1.645 & 1.830 & 0.141 & 2.062 & 115.48 \\
25.00 & 0.04 & 2.537 & 1.751 & 1.751 & 1.830 & 0.141 & 2.077 & 119.53 \\
50.00 & 0.02 & 2.797 & 2.054 & 2.054 & 1.830 & 0.141 & 2.120 & 131.93 \\
100.00 & 0.01 & 3.035 & 2.327 & 2.327 & 1.830 & 0.141 & 2.159 & 144.18 \\
200.00 & 0.005 & 3.255 & 2.576 & 2.576 & 1.830 & 0.141 & 2.194 & 156.38 \\
400.00 & 0.025 & 3.462 & 2.807 & 2.807 & 1.830 & 0.141 & 2.227 & 168.61 \\
\hline
\end{tabular}

Tabel 13. Karakteristik data hujan stasiun Surgi Mufti

\begin{tabular}{cc}
\hline Karakteristik data & Nilai \\
\hline X rerata & 1.830 \\
X median & 1.785 \\
Simpangan baku & 0.141 \\
Skewness Coefisien & 1.853 \\
Varuant coefisien & 12.935 \\
\hline
\end{tabular}

Tabel 14. Perhitungan probabilitas hujan rencana menurut Log Normal Stasiun Surgi Mufti

\begin{tabular}{ccccccccccc}
\hline $\mathrm{m}$ & $\mathrm{x}$ & $\log \mathrm{X}$ & $\begin{array}{c}\mathrm{P}=\mathrm{m} /( \\
\mathrm{n}+1)\end{array}$ & $\mathrm{W}$ & $\mathrm{Z}$ & $\mathrm{K}$ & $\begin{array}{c}\text { Log X } \\
\text { rata-rata }\end{array}$ & $\begin{array}{c}\text { Simp } \\
\text { baku }\end{array}$ & $\log \mathrm{XT}$ & $\mathrm{XT}$ \\
\hline 1 & 168 & 2.225 & 0.067 & 2.327 & 1.501 & 1.501 & 1.830 & 0.141 & 2.041 & 110.19 \\
2 & 91 & 1.959 & 0.133 & 2.007 & 1.111 & 1.111 & 1.830 & 0.141 & 1.987 & 97.03 \\
3 & 90 & 1.954 & 0.2 & 1.794 & 0.841 & 0.841 & 1.830 & 0.141 & 1.949 & 88.88 \\
4 & 75 & 1.875 & 0.267 & 1.626 & 0.623 & 0.623 & 1.830 & 0.141 & 1.918 & 82.76 \\
5 & 69 & 1.839 & 0.333 & 1.482 & 0.430 & 0.430 & 1.830 & 0.141 & 1.891 & 77.74 \\
6 & 66 & 1.820 & 0.4 & 1.354 & 0.253 & 0.253 & 1.830 & 0.141 & 1.866 & 73.37 \\
7 & 61 & 1.785 & 0.467 & 1.235 & 0.083 & 0.083 & 1.830 & 0.141 & 1.842 & 69.43 \\
8 & 61 & 1.785 & 0.533 & 1.121 & -0.083 & -0.083 & 1.830 & 0.141 & 1.818 & 65.76 \\
9 & 59 & 1.771 & 0.6 & 1.011 & -0.252 & -0.252 & 1.830 & 0.141 & 1.794 & 62.25 \\
10 & 55 & 1.740 & 0.667 & 0.901 & -0.428 & -0.428 & 1.830 & 0.141 & 1.769 & 58.79 \\
\hline
\end{tabular}


Lanjutan Tabel 14. Perhitungan probabilitas hujan rencana menurut Log Normal Stasiun Surgi Mufti

\begin{tabular}{ccccccccccc}
\hline $\mathrm{m}$ & $\mathrm{x}$ & $\log \mathrm{X}$ & $\begin{array}{c}\mathrm{P}=\mathrm{m} /( \\
\mathrm{n}+1)\end{array}$ & $\mathrm{W}$ & $\mathrm{Z}$ & $\mathrm{K}$ & $\begin{array}{c}\text { Log X } \\
\text { rata-rata }\end{array}$ & $\begin{array}{c}\text { Simp } \\
\text { baku }\end{array}$ & $\log \mathrm{XT}$ & $\mathrm{XT}$ \\
\hline 11 & 55 & $1 / 740$ & 0.733 & 0.788 & -0.616 & -0.616 & 1.830 & 0.141 & 1.743 & 55.28 \\
12 & 54 & 1.732 & 0.8 & 0.668 & -0.829 & -0.829 & 1.830 & 0.141 & 1.713 & 51.59 \\
13 & 50 & 1.699 & 0.867 & 0.535 & -1.084 & -1.084 & 1.830 & 0.141 & 1.676 & 47.47 \\
14 & 49.1 & 1.691 & 0.933 & 0.371 & -1.435 & -1.435 & 1.830 & 0.141 & 1.627 & 42.34 \\
\hline & Realita & & & & \multicolumn{7}{c}{ Teoritis } \\
\hline $\mathrm{X}$ & 71.650 & $\mathrm{CS}$ & 2.682 & & & $\mathrm{X}$ & 70.206 & $\mathrm{CS}$ & 0.564 \\
$\mathrm{~s}$ & 30.728 & $\mathrm{CV}$ & 2.332 & & & $\mathrm{~s}$ & 19.649 & $\mathrm{CV}$ & 3.591 \\
\hline
\end{tabular}

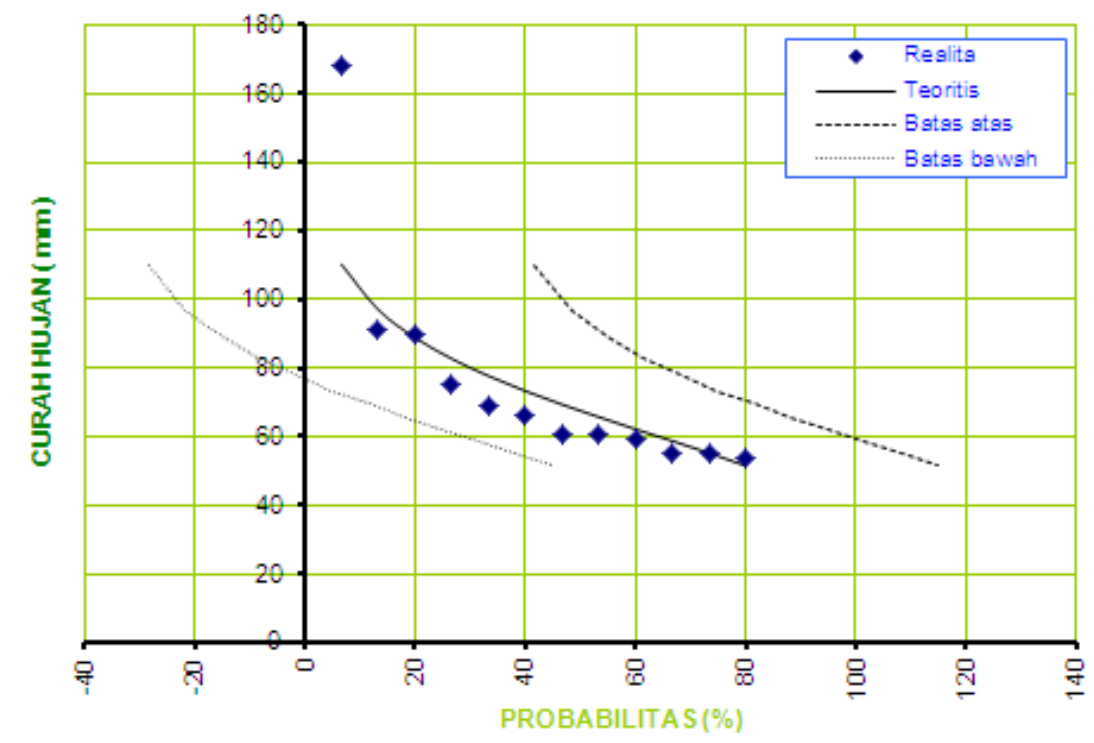

Gambar 5. Hubungan antara probabilitas dan curah hujan Surgi Mufti menurut metode Log Normal

Tabel 15. Rekapitulasi hujan rencana stasiun hujan Surgi Mufti

\begin{tabular}{|c|c|c|c|c|}
\hline \multirow[b]{2}{*}{$\mathrm{TP}$} & \multicolumn{3}{|c|}{ Hujan Rencana (mm) } & \multirow[b]{2}{*}{ Keterangan } \\
\hline & Gumbel & $\begin{array}{c}\text { Log Pearson } \\
\text { III } \\
\end{array}$ & Log Normal & \\
\hline 2.00 & 67.66 & 60.54 & 67.57 & \multirow{10}{*}{$\begin{array}{l}\text { Dengan memperhatikan hasil dari Chi-Test } \\
\text { yang menunjukkan angka dibawah 5\% dan } \\
\text { hasil Uji Smirnov dengan nilai terkecil, } \\
\text { maka Pemilihan Distribusi Log Pearson } \\
\text { Type III lebih dapat diterima dan } \\
\text { ditunjuang dengan nilai CS dan CV yang } \\
\text { lebih mendekati realita. }\end{array}$} \\
\hline 5.00 & 102.72 & 82.42 & 88.88 & \\
\hline 10.00 & 125.93 & 104.35 & 102.58 & \\
\hline 15.00 & 139.02 & 119.93 & 110.19 & \\
\hline 20.00 & 148.19 & 132.44 & 115.48 & \\
\hline 25.00 & 155.25 & 143.09 & 119.53 & \\
\hline 50.00 & 177.01 & 182.27 & 131.93 & \\
\hline 100.00 & 198.60 & 232.84 & 144.18 & \\
\hline 200.00 & 220.11 & 298.32 & 156.38 & \\
\hline 400.00 & 241.59 & 383.34 & 168.61 & \\
\hline \multicolumn{4}{|c|}{ Teoritis } & Realita \\
\hline $\mathrm{X}$ rerata & 69.697 & 67.590 & 70.206 & 71.650 \\
\hline CS & 0.551 & 1.671 & 0.564 & 2.682 \\
\hline $\mathrm{CV}$ & 2.820 & 3.400 & 3.591 & 2.332 \\
\hline $\mathrm{S}$ baku & 24.712 & 19.882 & 24.917 & 30.728 \\
\hline Chi Test & 0.001 & 0.085 & 0.001 & \\
\hline
\end{tabular}




\section{Debit Banjir Rencana}

Debit banjir rencana dihitung berdasarkan hujan rencana yang disimulasikan untuk masing-masing DAS.
Masing-masing DAS mempunyai Sub DAS memiliki bentuk DAS, luas, panjang sungai, topografi, dan kerapatan jaringan kuras yang berbeda.

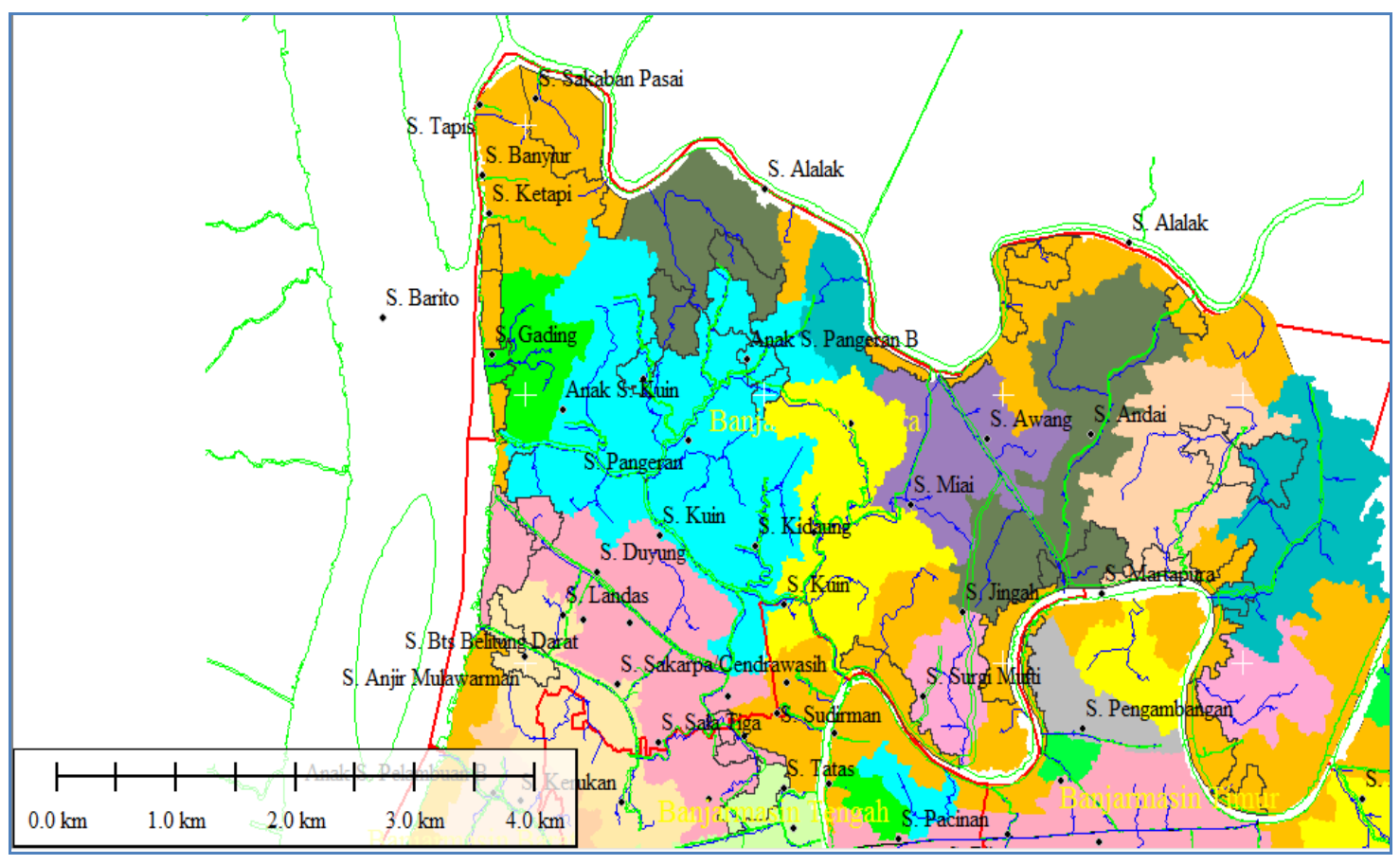

Gambar 6. Pembagian sub DAS pada sistem Drainase Kota Banjarmasin kawasan Banjarmasin Utara

\section{Analisa genangan}

Seperti diketahui bahwa genangan yang terjadi di Kota Banjarmasin disebabkan oleh air sungai pasang, air hujan maupun hujan yang bersamaan dengan air sungai pasang.

Air sungai Barito dan Sungai Martapura pada saat pasang tinggi berada di atas sebagian lahan di kota Banjarmasin. Sehingga air pasang tersebut dapat menggenangi lahan yang berada di bawah permukaan air pasang. Gambar
5.13 sampai dengan Gambar 5.18 menunjukan lahan-lahan memungkinkan tergenang karena elevasinya berada dibawah permukaan air pasang. Pada saat elevasi air pasang sungai +2.00 , hanya sebagian wilayah di kawasan banjarmasin utara yang tergenang. Pada kondisi air pasang +2.50, wilayah kawasan banjarmasin utara yang memiliki topografi cukup tinggi tidak berpotensi tergenang air. Sedangkan selebihnya hampir sebagian besar wilayah berpotensi tergenang. 


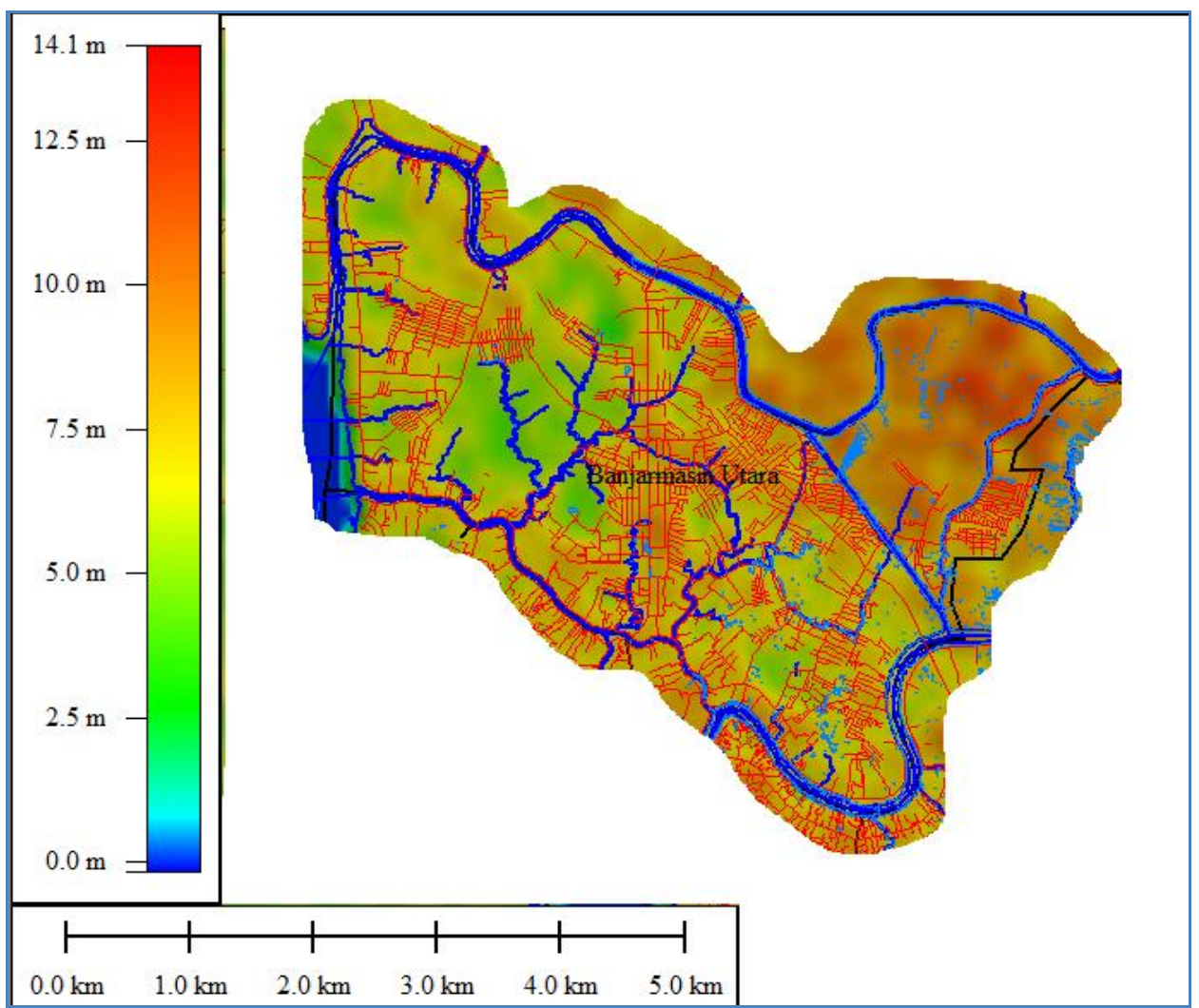

Gambar 7. Genangan akibat elevasi pasang dengan muka air sungai +2.00

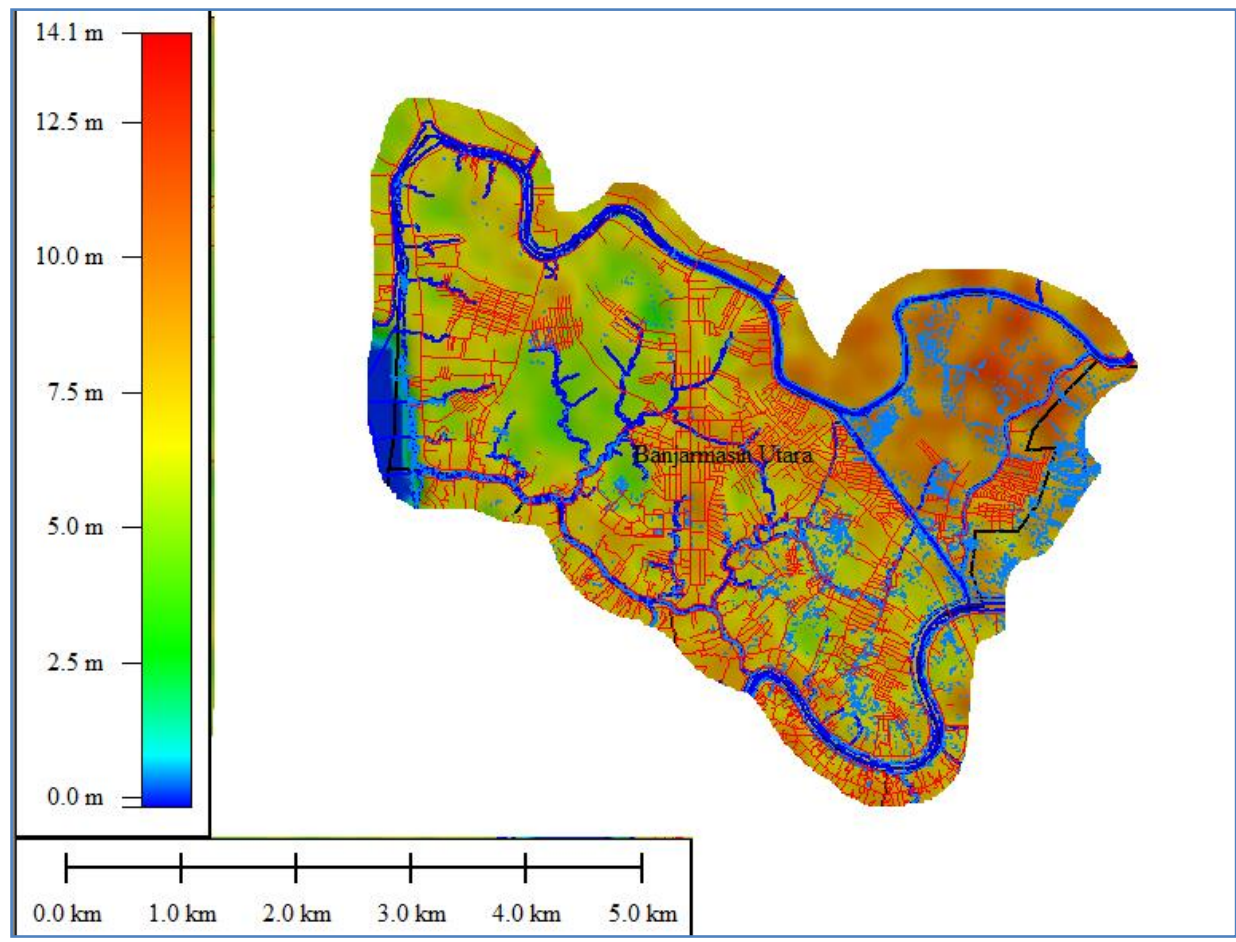

Gambar 8. Genangan akibat elevasi pasang dengan muka air sungai +2.1 


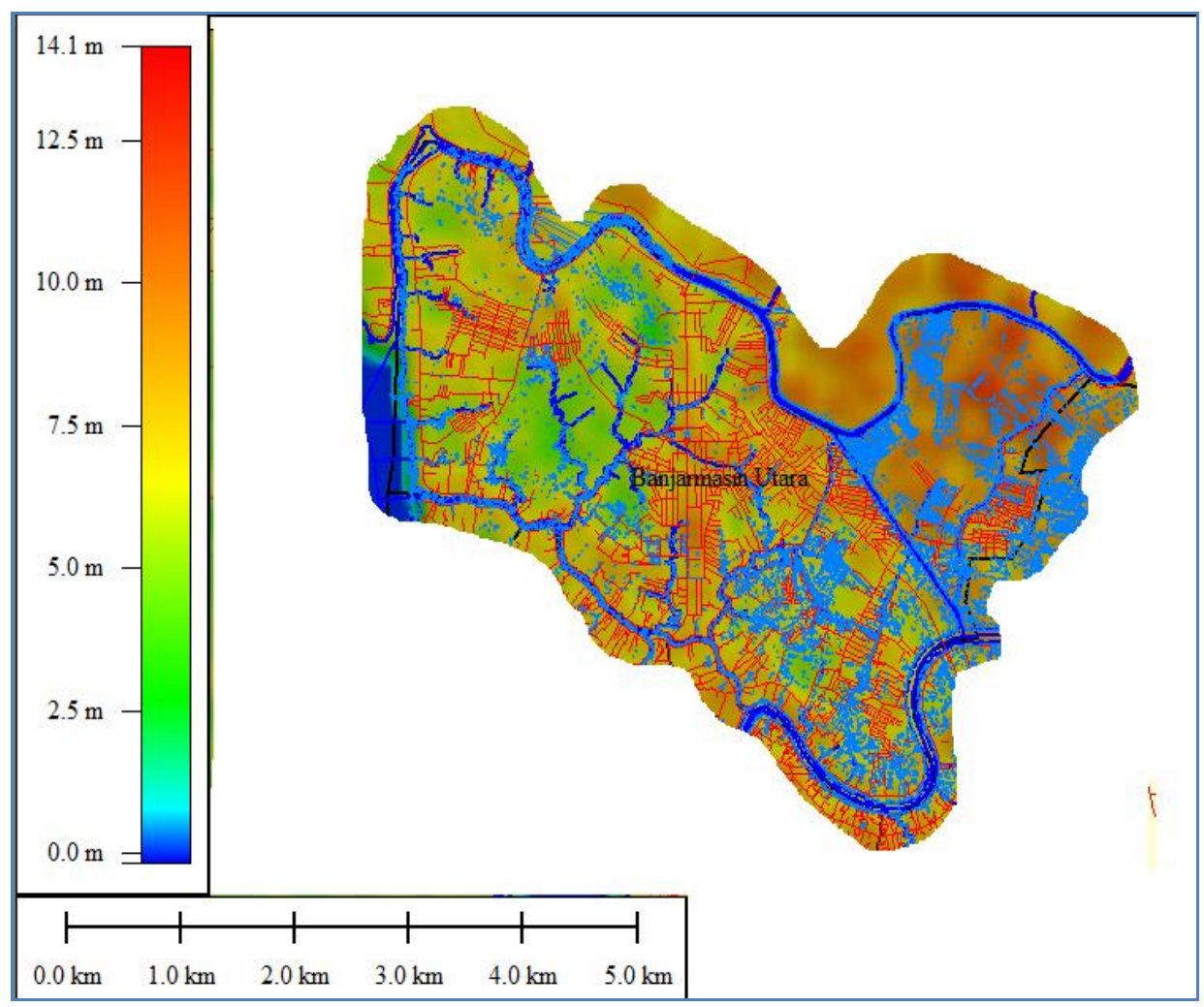

Gambar 9. Genangan akibat elevasi pasang dengan muka air sungai +2.20

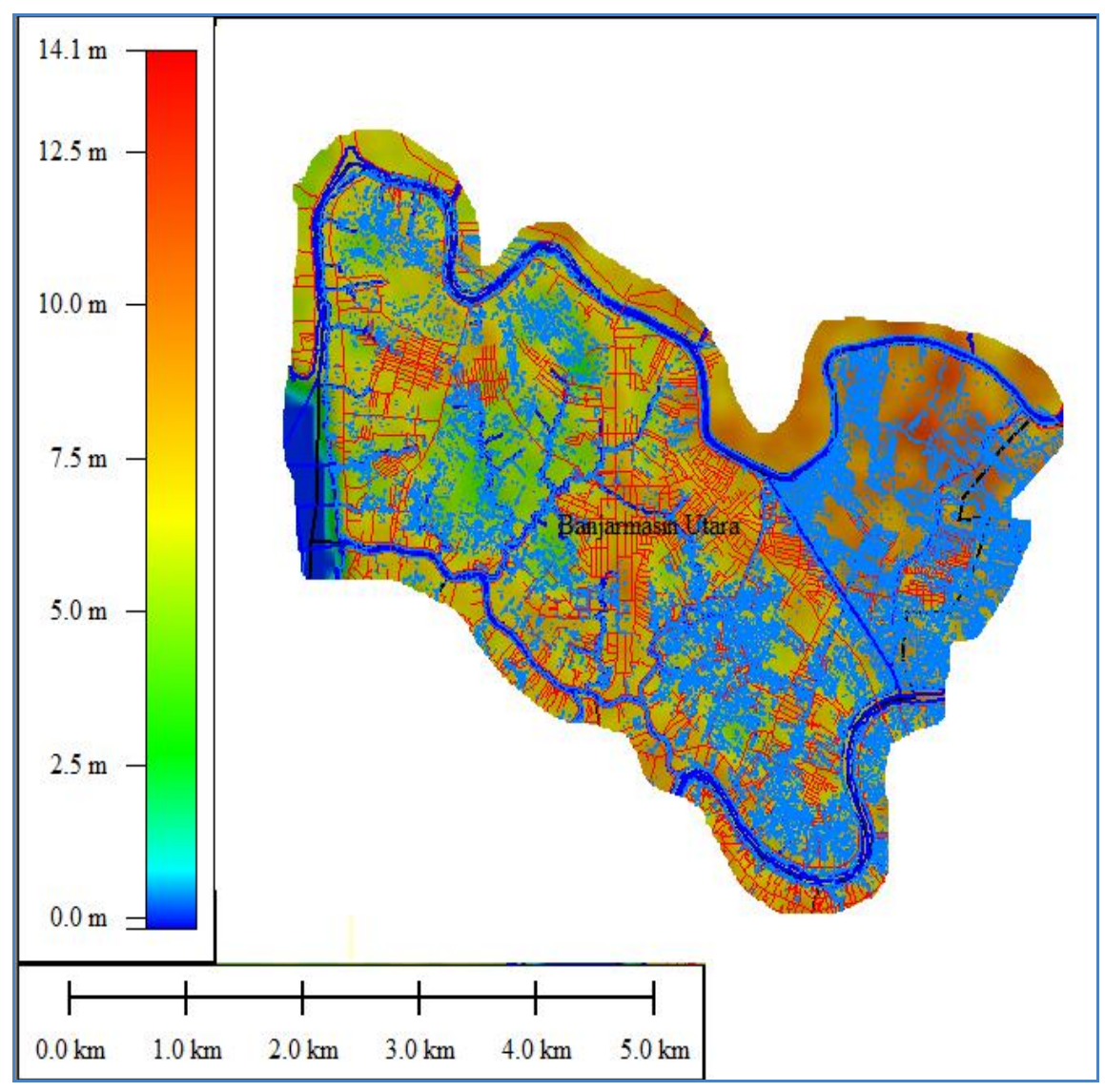

Gambar 10. Genangan akibat elevasi pasang dengan muka air sungai +2.30 


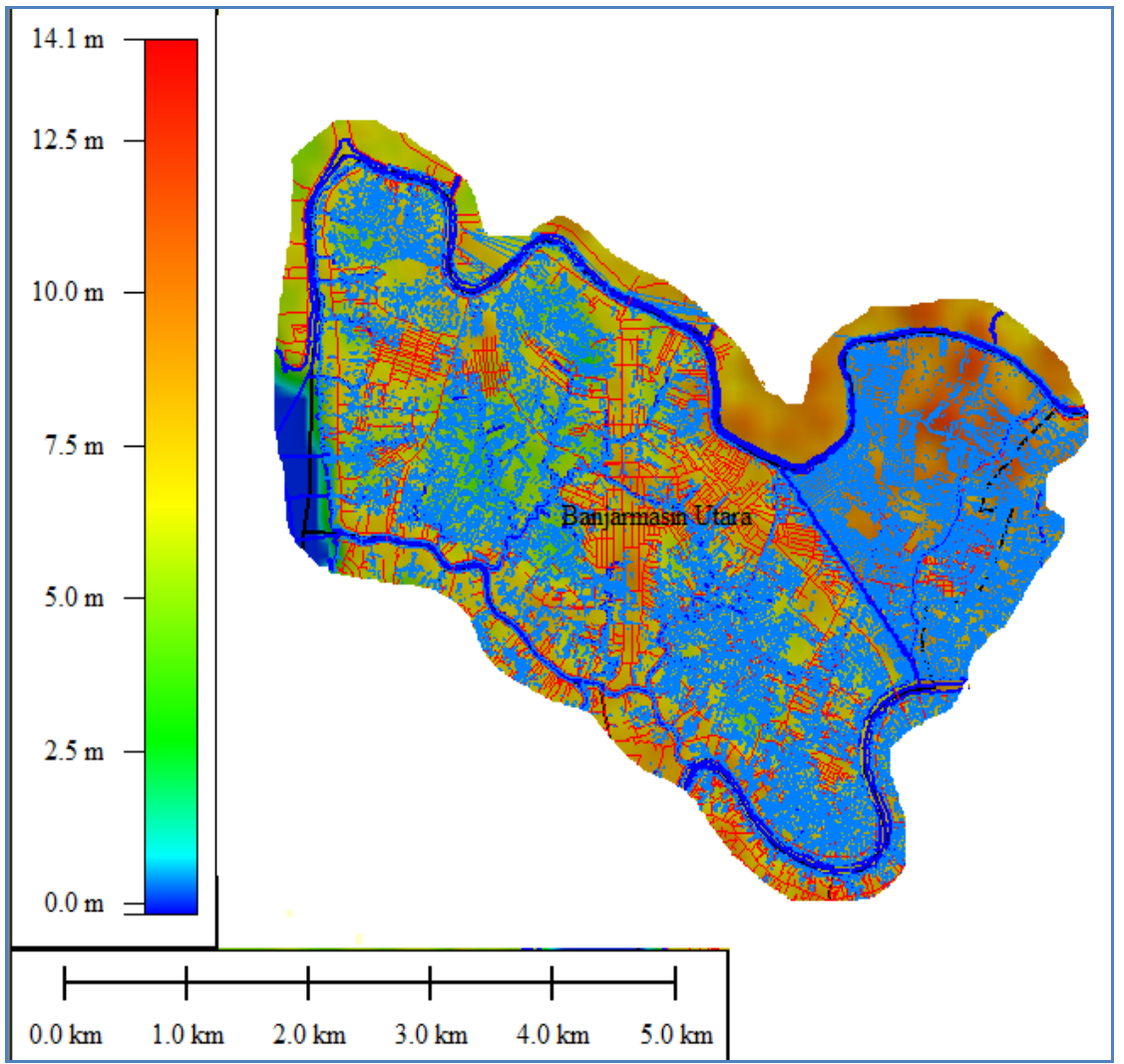

Gambar 11. Genangan akibat elevasi pasang dengan muka air sungai +2.40

Peta Genangan Genangan Pada Beberapa Sub DAS

Simulasi peta genangan ditunjukan pada beberapa Sub Das di kawasan Banjarmasin Utara. Pemetaan genangan dilakukan di daerah - daerah yang berpotensi tergenang. Model peta dikembangkan dari survey genangan yang dilakukan di kelurahan - kelurahan banjarmasin utara dan dari kondisi topografi kawasan.

a. Sub DAS Andai

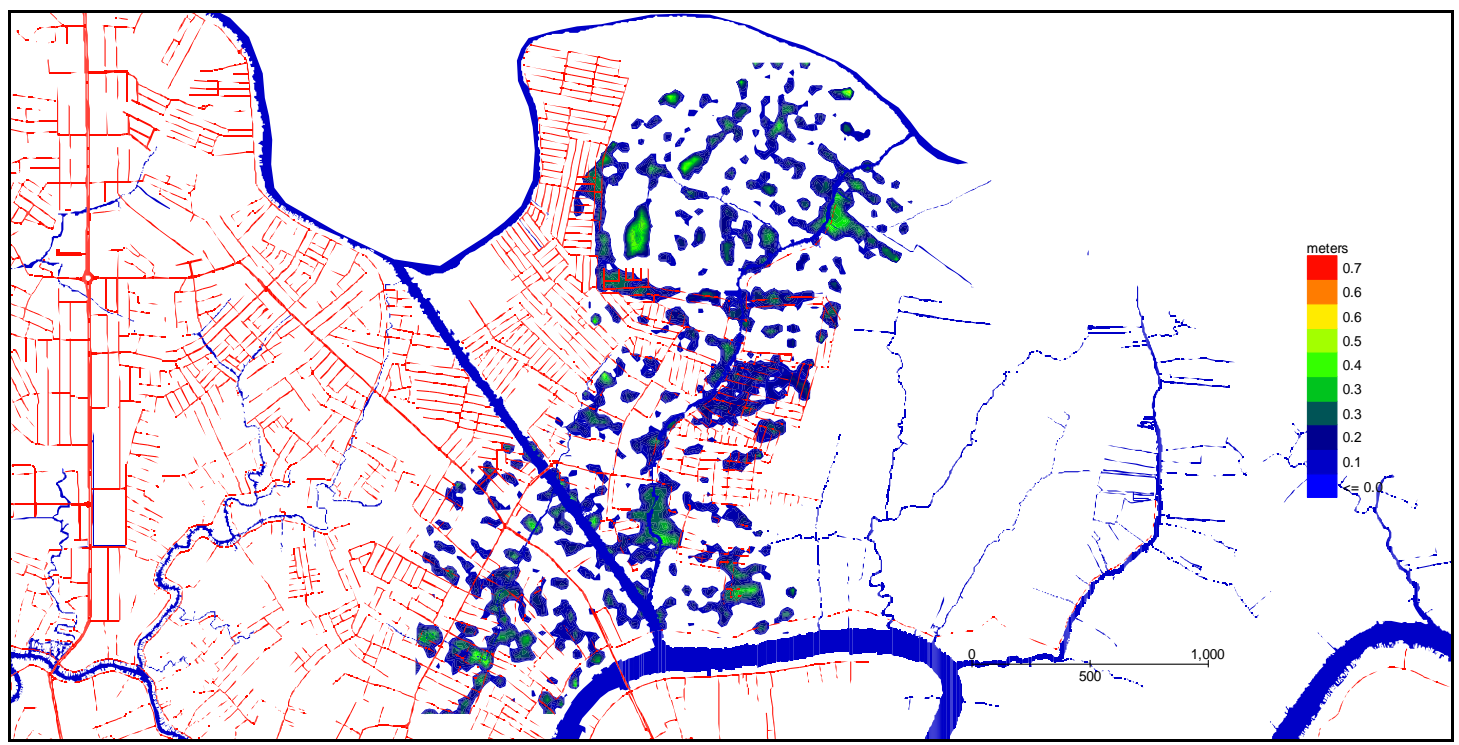


b. Sub DAS Awang

Gambar 12. Genangan di Sub DAS And

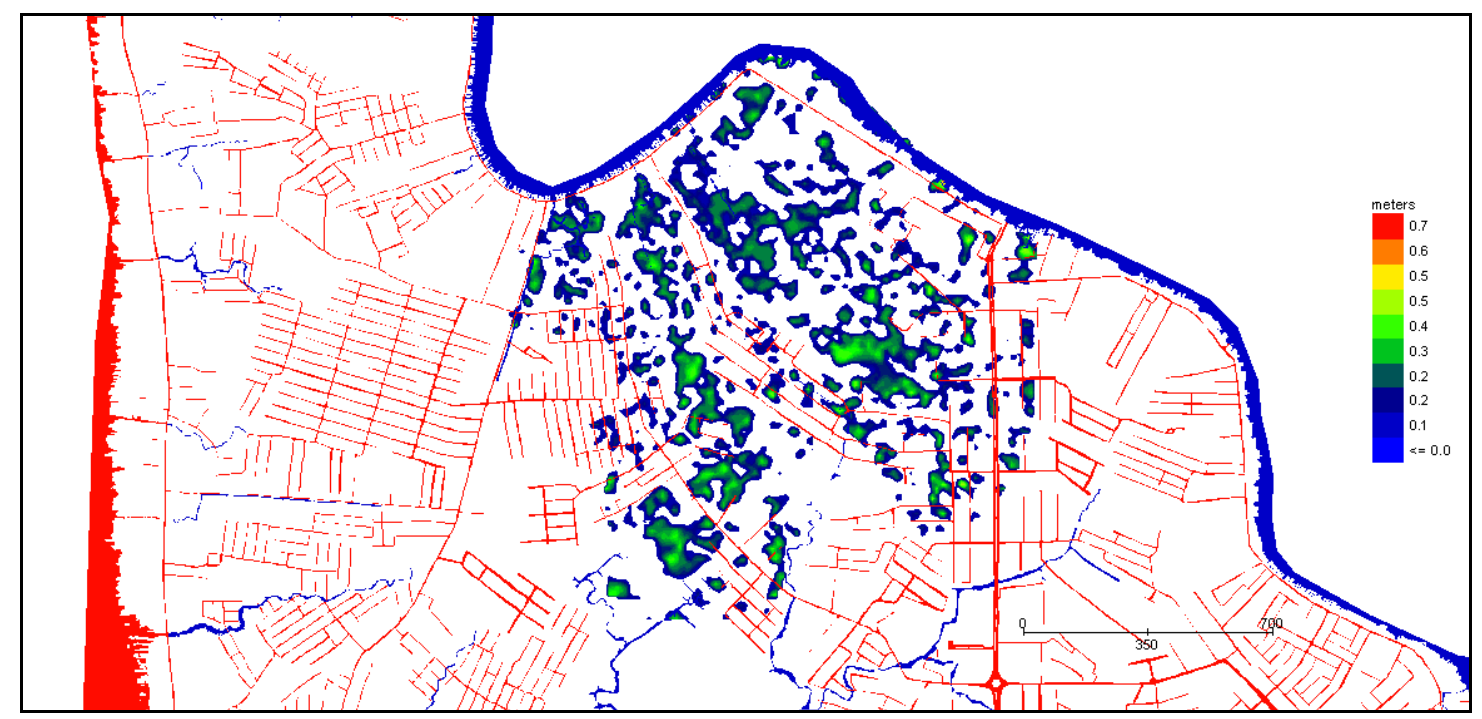

Gambar 13. Genangan di Sub DAS Awang

c. Sub DAS Jahri Saleh

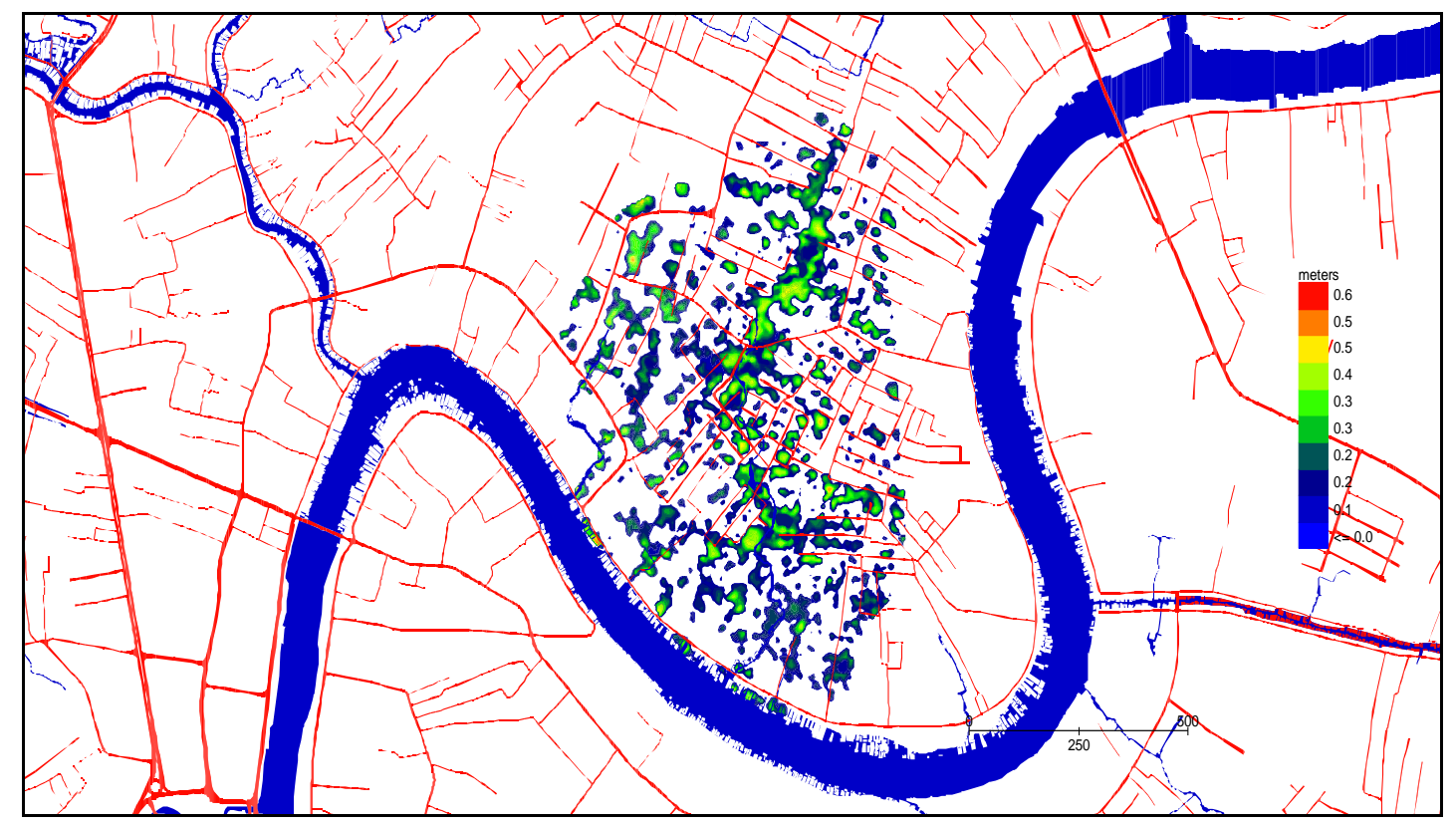

Gambar 14. Genangan di Sub DAS Jahri Saleh 
d. Sub DAS S.Jingah

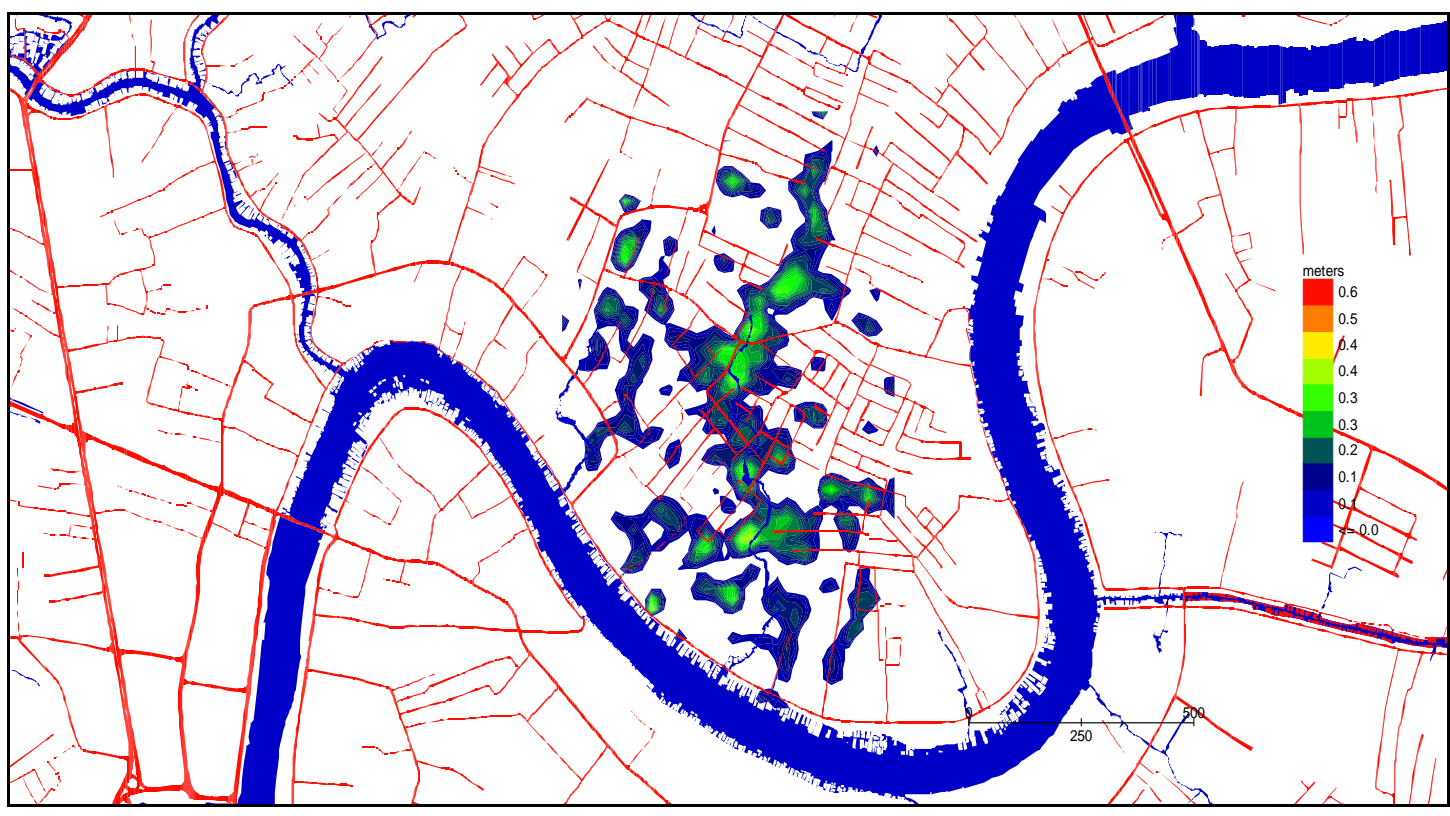

Gambar 15. Genangan di Sub DAS S. Jingah

e. Sub DAS Kuin

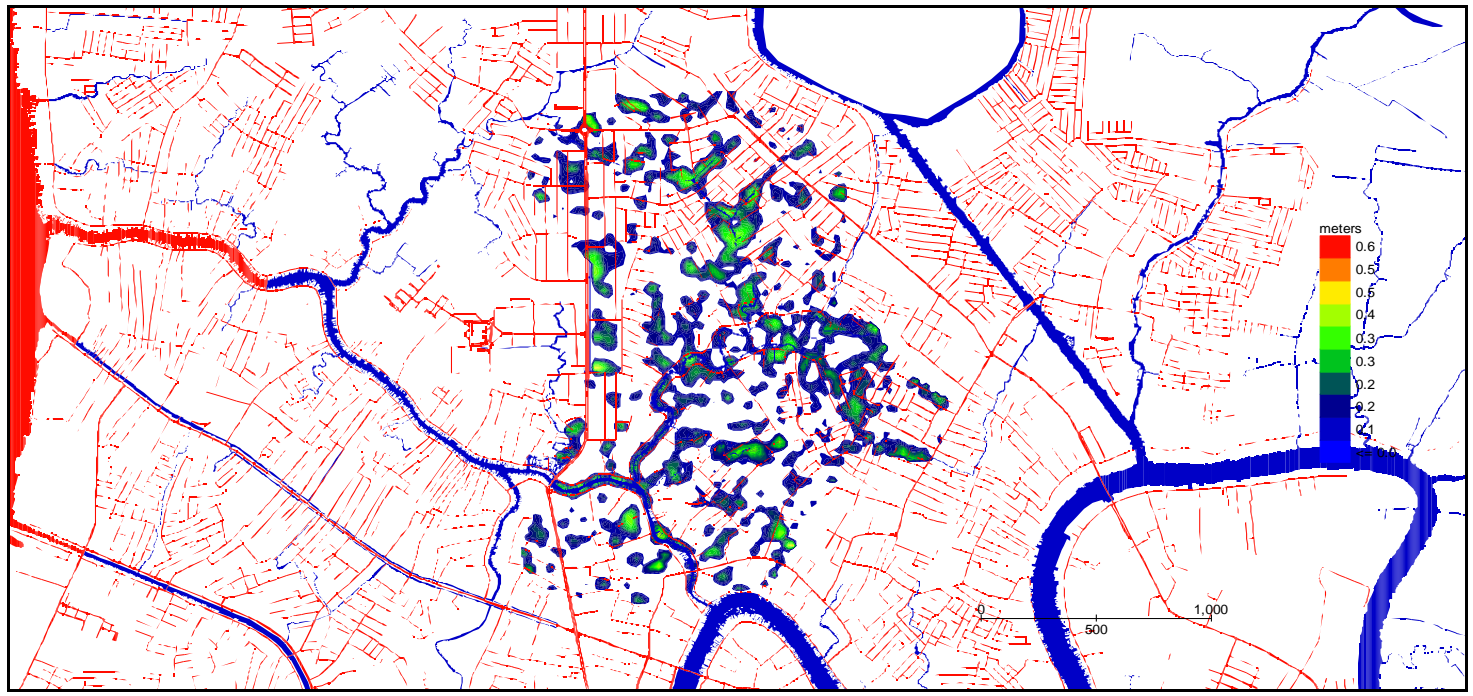

Gambar 16. Genangan di Sub DAS Kuin

\section{KESIMPULAN}

Penyebab genangan di kawasan Banjarmasin Utara antara lain :

- Saluran drainase belum semuanya terbangun di kawasan tersebut, terutama dikawasan genangan.
- Kurang oftimalnya fungsi drainase disebabkan kurangnya pemeliharaan bangunan drainase.

- Terdapatnya sedimentasi yang menyebabkan pendangkalan secara cepat dari saluran sekunder dan tersier.

- Inlet dari jalan kesaluran tidak dapat berfungsi dengan baik. 
- Hambatan aliran dalam saluran yang disebabkan oleh tumbuhan air, sampah, pipa-pipa dll.

- Aliran balik akibat pengaruh pasang air Sungai Brito dan Martapura.

- Penyempitan alur sungai dan anak sungai oleh bangunan sehingga kapasitas tampung tidak mencukupi lagi.

- Berkurangnya lahan tempat penampungan dan peresapan air akibat berubah menjadi lahan bangunan.

\section{DAFTAR PUSTAKA}

Fitriansya, Ir, MT. Bahan Ajar Rekayasa Hidrologi. Fakultas Teknik
Universitas Achmad Yani Banjarmasin

Suripin, Dr. Ir. M. Eng. Sistem Drainase Perkotaan Yang Berkelanjutan. Andi. Yogyakarta

Rozali Achmad, M.Sc. Diklat Aplikasi GPS (GIS) Dalam Perencanaan Jalan (Manual Global Mapper). Kementerian Pekerjaan Umum. Jakarta

T. Reinhart PS, Ir. Dipl.H. Diklat Pengendalian Banjir Perkotaan. Kementerian Pekerjaan Umum. Jakarta

Pemerintah Kota Banjarmasin. Peraturan Daerah Kota Banjarmasin Nomor 5 Tahun 2013 Tentang Rencana Tata Ruang Wilayah Kota Banjarmasin Tahun 2013-2032. Banjarmasin 